\title{
AFTERWORD
}

\section{The Role of a Bill of Rights}

\author{
David A. Strauss $\dagger^{\dagger}$
}

One of the happiest facts about the two hundredth anniversary of the Bill of Rights is that it occurs when, for many people in the world, the question whether to adopt a bill of rights is alive for the first time. What will they be adopting, if they adopt a bill of rights? In this Afterword I want to suggest an answer to that question, based on the American experience with the Bill of Rights generally and, in particular, with controversies of the kind reflected in the articles in this issue.

My suggestion is that there are three different conceptions of the Bill of Rights. Each conception sees the Bill of Rights as serving a different purpose. Each rests on certain normative and institutional premises. Each gives rise to a characteristic form of argument. None of these three conceptions, I will argue, is obviously wrong.

Many controversies that appear to concern the proper interpretation of a provision of the Bill of Rights, including many of the debates in this issue, are in fact contests between or among these different conceptions of the Bill of Rights. Disputes of this kind cannot be resolved until one conception of the Bill of Rights can be justified over another. Many confusions, illegitimate arguments, and unwarranted displays of defensiveness derive from the failure to realize that what is at stake in controversies about the Bill of Rights is often differing conceptions of the Bill of Rights.

In Sections I, II, and III of this essay, I describe the three conceptions. The first conception views the Bill of Rights as a code: a

\footnotetext{
t Professor of Law, The University of Chicago. I am grateful to Elena Kagan, Lawrence Lessig, Geoffrey Stone, and Cass Sunstein for comments on an earlier draft.
} 
list of relatively specific requirements and prohibitions. The second treats the Bill of Rights as a means of correcting some of the systematic failures of representative government. The third views the Bill of Rights as a charter of fundamental human rights that should not be invaded in any society. In Section IV, I will conclude by describing five fallacies that, I believe, often occur in arguments about the Bill of Rights. These fallacies result from adopting one or another conception without realizing that it is just one possible conception, and without justifying it in preference to the other conceptions.

I do not mean to suggest that everyone must adopt one or another conception. Each conception may be true to some degree. But whichever conception or combination of conceptions one adopts must be justified. One cannot simply assume that an approach derived from one or another conception is the only correct way to interpret the Bill of Rights.

I also do not mean to endorse any controversial theory of interpretation. I do, however, necessarily reject a theory of interpretation that perhaps has some adherents. That is the view that the correct interpretation of the Bill of Rights is entirely determined by the text alone, by history, by precedent, or by some similar source of authority, and that arguments about justice or social welfare can play no role in its interpretation. Of course, text and history play a role, but they do not dictate one conception and foreclose all the others. To some degree, the choice among the competing conceptions must be made in light of the considerations I discuss below.

\section{The Bill of Rights As a Code}

A.

What would be most striking about the Bill of Rights to a stranger to our culture who was reading it for the first time? One plausible answer is something that played almost no role in the articles presented at this symposium: the detailed code of protections for criminal defendants. The Sixth Amendment is entirely a catalogue of such protections. The Fifth Amendment is also, except for the Just Compensation Clause. ${ }^{1}$ The Eighth Amendment

\footnotetext{
1 For an account of why the Just Compensation Clause is included, incongruously, with a list of protections of criminal defendants, see Akhil Reed Amar, The Bill of Rights As a Constitution, 100 Yale L J 1131, 1181-82 (1991). The Due Process Clause of the Fifth Amendment, of course, applies to civil as well as criminal proceedings.
} 
applies only to criminal punishments. The Fourth Amendment applies principally to criminal investigations and arrests. Since the Second and Third Amendments have little practical significance, the Seventh Amendment does not apply to the states, and the Ninth and Tenth Amendments are often not regarded as part of the Bill of Rights, specific protections for criminal defendants are arguably the dominant feature of the Bill of Rights.

A celebration of the one hundred and seventy-fifth anniversary of the Bill of Rights would have paid a great deal of attention to this aspect of the document. For three decades, culminating in the 1960s, the Supreme Court reformed state criminal procedure, principally on the authority of the specific guarantees of the Fourth, Fifth, Sixth, and Eighth Amendments. ${ }^{2}$ The Court used two complementary doctrinal tools in pursuing this agenda: incorporation and literalism. Incorporation, of course, is the view that the Due Process Clause of the Fourteenth Amendment applies the guarantees of the first eight amendments to the states. The most famous version of incorporation, Justice Black's, held that the Fourteenth Amendment applies each of those guarantees, but nothing more, to the states, in exactly the way that the original Bill of Rights applies to the federal government. Literalism insists that the words of the first eight amendments impose relatively clear requirements that must be followed. Justice Black reviled what he called the "natural law due process formula" under which government action could be upheld so long as it satisfied a test of "fundamental fairness" or consistency with "ordered liberty."3

In using the Bill of Rights in this way, the Court was following in a great tradition of law reform. The Court was using the Bill of Rights as a code-a list of specific, relatively determinate prohibitions and requirements. The criminal law reform movement of the late eighteenth century and early nineteenth century was also a codification movement. Jeremy Bentham, perhaps the most prominent reformer in England, was outspoken in his condemnation of the common law, which he viewed as the enemy of reform. Only a code-a catalogue of specific rules-could bring about changes in

\footnotetext{
2 Before 1960, the Court relied principally on the Due Process Clause of the Fourteenth Amendment alone. See, for example, Chambers $v$ Florida, 309 US 227 (1940); and Powell $v$ Alabama, 287 US 45 (1932). Beginning in 1961, the Court began to apply the specific guarantees of the Bill of Rights to the states through the Due Process Clause. See the cases cited in Duncan v Louisiana, 391 US 145, 148 \& nn 4-12 (1968).

${ }^{3}$ For especially clear statements of Justice Black's position on both issues, see Duncan, 391 US at 162 (Black concurring); Adamson v California, 332 US 46, 68 (1947) (Black dissenting).
} 
criminal law. Justice Black's animadversions against the "natural law due process formula" echoed Bentham's ridicule of natural rights and the common law. ${ }^{4}$

Both Bentham and Black understood that a code can be a reformer's ally, and an open-ended natural law or fundamental fairness approach can be a reformer's enemy. If you are trying to uproot practices that have existed for many years but that you think are corrupt or harmful, a "fundamental fairness" standard will seldom do the job. Committed reformers will agree that those practices are unfair. But a large-scale reform effort will not succeed unless it is also implemented by lower-level officials-bureaucrats, or judges of lower courts-who will do their jobs in good faith but who are not necessarily committed to the reform effort.

Such lower-level officials will tend to identify "fairness" with existing practices. If, however, they are responsible for enforcing a more determinate norm, they are more likely to decide that their duty requires them to uproot an established practice. It will be difficult for a person who has worked within a system in which, say, prosecutors have been allowed to comment on an accused's failure to testify at trial, to conclude that such a system is fundamentally unfair. It will be easier for such a person to conclude that the system violates the specific prohibition against compelled self-incrimination. That is not because the language deductively requires that result; of course it does not. But it is easier for a person to justify that result, to herself and others, if the specific norm rather than a more general principle is in force. And a specific norm makes it easier for a person to disclaim responsibility for the decision by blaming it on the text, or the framers, or the codifiers.

This is also true outside criminal law as well. An Eastern European official who is trying to uproot a tradition of state control over an economy and to establish a market is likely to find that specific limitations on officials' authority are more effective than general injunctions to "use price mechanisms" or "promote private ownership." Max Weber associated the rise of capitalism with codes and rule-governed bureaucracies, ${ }^{5}$ and while this association did not invariably hold, the reason for it is clear: entrenched patterns of privilege that prevent markets from developing will yield more readily to rule-governed forms of political organization than

\footnotetext{
- See, for example, H.L.A. Hart, ed, Jeremy Bentham, Of Laws in General 152-95 (London, 1970).

s See Max Rheinstein, ed, Max Weber, Law in Economy and Society 350-56 (Harvard, 1954).
} 
to a regime in which lower-level officials are controlled by less determinate norms.

One use of a bill of rights, then, is to serve as a code that facilitates reform-a specific list of requirements or prohibitions to help break up traditional practices that are in need of change.

\section{B.}

This conception of the Bill of Rights carries with it certain presuppositions. First notice, however, one thing that it does not presuppose: Nothing in this understanding of the Bill of Rights requires any form of judicial supremacy. A code-that is, a relatively specific catalogue of requirements and prohibitions-can be adopted by a legislature as a tool of reform. Bentham and other codifiers urged their codes on Parliament. Far from being initiators of reform, judges were the problem: the reluctant, tradition-bound officials who needed the sharp edges of a code, rather than the more gentle prodding of an open-ended norm, if they were to effect reform.

A code can be addressed to legislatures, too. International human rights treaties are an example. A treaty requiring nations to protect a specific catalogue of human rights is easier to enforce than a general rule requiring respect for humanity. Violations of specific rights can be identified and condemned with greater ease and greater effect, and without the need to argue over whether the practice violates an open-ended norm. The Supreme Court's use of the Bill of Rights to reform American criminal procedure was just a particular instance of a code-driven reform effort led by a court. The connection between the use of the code and the role of the Court was contingent.

This conception of a bill of rights does presuppose some state of affairs that needs reform badly enough to justify the costs inflicted by a code. A code, like any set of rules, is a crude device. It will be over- and under-inclusive. Some practices that will be found to violate, for example, the Double Jeopardy Clause or the Self-Incrimination Clause, might be practices that, everything considered, should be maintained. Conversely, some unjust practices might not violate any specific provision of the Bill of Rights; ideally they should be invalidated, but under the "code" conception of the Bill of Rights they will survive.

It makes no sense to incur these costs of over- and under-inclusiveness unless there is a potential gain. If, for example, there are entrenched practices that will yield to strict rules but not to more open-ended norms, the price might be justified. 
C.

This conception of the Bill of Rights has two characteristic modes of argument, which I will call formalism and exclusivity. By formalism I mean three things: a heavy reliance on the precise language of the text; a pretense that the text resolves more issues than it actually does; and an effort to shift responsibility for a decision away from the actual decisionmaker and to some other party, such as the Framers. Justice Black's opinions are famous for displaying these traits. By exclusivity I mean the insistence that the catalogue of rights is exhaustive; that no other rights besides those enumerated in the code exist. This, of course, was one of Justice Black's central themes.

Formalism and exclusivity are necessary to this conception because otherwise the Bill of Rights would not serve the functions of a code: it would not provide the clarity needed for reform. A code forces officials to judge a traditional practice, which they might be inclined to uphold, in light of relatively specific language. If the officials can escape the language, they are more likely to follow their tendency to uphold the traditional practice, and the reform mission will fail.

They can escape the language by deemphasizing its importance, for example by saying that the specific guarantees of the Bill of Rights inform but do not determine the proper interpretation of the Fourteenth Amendment. Or they might escape the language by capitalizing on its indeterminacy, for example by saying that the words of the Self-Incrimination Clause do not, by virtue of their meaning alone, preclude the government from commenting on a defendant's failure to testify.

One might ask why, if the words of a constitutional provision do not actually require that a traditional practice be overthrown, judges who are disposed to accept the practice will feel that the words compel them to overthrow it. The answer, I believe, is that formalism is an attractive creed to people who have the power to make decisions. Formalism makes difficult decisions easier, in at least two ways. First, a formalist decisionmaker generally doesn't have to think as hard; she only has to work with the words of the authoritative text, instead of with complex and (obviously) inconclusive arguments about policy or fairness. Second, a formalist decisionmaker can more readily assign responsibility for the decision elsewhere. Because formalism is so attractive, a legislature, supreme court, or chief executive who promulgates a code and sets about creating a formalist legal culture can expect to have some 
success in inducing officials to act like formalists, even when that means that they will take part in uprooting a practice that they themselves do not consider unfair.

Exclusivity-we enforce the Bill of Rights; nothing less, but nothing more-functions in a more indirect way, by enhancing the credibility of the reformers. It allows them to appear restrained and principled. Like formalism, it helps assign responsibility elsewhere. Justice Black's position is again the paradigm. He criticized the Court for overreaching when, as in Griswold v Connecticut, ${ }^{6}$ it enforced rights not clearly specified in the Bill of Rights. This allowed him to convey the message that he was willing to be bound by the same restraints he imposed on the states and on the other branches of the federal government. Self-denial of this form gives credibility to the claim that the reformers' efforts are not simply their own acts of will.

\section{D.}

The problems with the formalistic conception of the Bill of Rights are well known. The language, even of the most specific provisions, is not determinate; the words alone resolve few controversial cases. There are notorious problems in relying on the Framers' intentions as a way of making the language more determinate. The argument for exclusivity is dubious, in light of, among other things: the Ninth Amendment; the indeterminacy of many of the specific guarantees in the Bill of Rights (a wide range of invasions of personal autonomy, for example, can plausibly be characterized as unreasonable seizures of the person); and the fact that the only language that literally applies to the states is the open-ended terms of Section 1 of the Fourteenth Amendment.

Perhaps the more difficult task is not to explain why the code conception need not be accepted as the only correct view, but rather to explain how anyone could ever accept it as the correct view. Perhaps the formalistic view of the Bill of Rights as a code should simply be rejected outright as obviously wrong and disingenuous. But I would like to describe, without endorsing, an argument that in some circumstances it would be defensible to adopt this conception of the Bill of Rights.

381 US 479 (1965).

- See, for example, Paul Brest, The Misconceived Quest for the Original Understanding, 60 BU L Rev 204 (1980); Ronald Dworkin, The Forum of Principle, 56 NYU L Rev 469, 476-500 (1981). 
Suppose you were a Supreme Court Justice at a time when, you believed, many states' criminal justice systems were badly in need of reform. On their face the states' procedural rules were reasonable, even enlightened. For example, they permitted criminal defendants to be compelled to testify, but only before a judge, in open court, with counsel present; they permitted trials before a judge in some complex cases, even when the defendant requested a jury; in the interests of "nonadversary" justice, they provided for appointment of counsel only when there was a special need; and they permitted some witnesses to give evidence without cross-examination. But you were convinced that these reasonable-sounding procedures masked abuses-in particular the frequent conviction of innocent defendants and racial discrimination-that were widespread but hard to prove in any specific case.

Although the particulars are different, this is arguably the situation that the Supreme Court faced between 1930 and 1970. In effect, Justice Black's response was: We do not wish either to condemn or to praise these procedures. That is not our role. Our role is to enforce the Constitution. But the words of the Bill of Rights simply prohibit each of these practices. We therefore cannot allow them to continue.

By contrast, a completely candid Court might say the following. Whether these procedures violate the specific provisions of the Constitution is by no means an open-and-shut question. One could interpret the Sixth Amendment right to counsel not to require the appointment of counsel in any case, but only to ensure that the defendant may have counsel that she herself retains. (Indeed, that was probably the Framers' understanding.) It would be more of a stretch, but one could interpret the self-incrimination and jury trial rights to apply only in cases of potential abuse. The Confrontation Clause might be interpreted to allow a trial court to dispense with cross-examination in favor of some other reasonably effective way of testing a witness's credibility. In any event, the only provisions that literally apply to the states are those of the Fourteenth Amendment, and on their face, the state procedures do not violate "due process of law," if that is interpreted to require only fundamental fairness. Nonetheless, the candid Court would say, we believe that these practices have led to serious abuses, and our interpretation of the Bill of Rights is informed by that belief. We accordingly hold that they are unconstitutional.

To the extent the Court's rhetoric matters, there is not much doubt which of these approaches is more likely to succeed. The first approach, Justice Black's, appeals to a widespread allegiance 
to the language of the Bill of Rights; it assigns a fully plausible, even obvious, meaning to its terms; and it does not appear to be passing moral judgment on the states. The second approach accuses state officials of reprehensible conduct, does not rely on specific language, and explicitly invokes the Court's conception of fairness. If you believed that the states' procedures needed reform, there is not much doubt which strategy is better calculated to achieve your aims.

Even if the formalist approach would be more effective, however, it might still be unacceptably disingenuous. ${ }^{8}$ Ordinarily one would want to say that deceptive and manipulative rhetoric is justified only in the most extreme circumstances. ${ }^{9}$ But in defense of the formalist approach, one might say that a judicial opinion is, and is understood to be, a public document, issued in part to accomplish certain effects. It is not expected to be a completely candid account of the judges' actual reasons for their decision.

For example, a court might set aside an agency action because it is convinced that the agency was influenced by improper political considerations, without saying so explicitly. It might set aside a state referendum because it believed the voters acted out of racial prejudice, without explicitly saying that. The most important decision of this century, Brown v Board of Education, ${ }^{10}$ is, notoriously, not fully candid in this sense. A fully candid opinion would have said (as the most compelling subsequent defense of the decision said $^{11}$ ) that segregation as practiced in the South in 1954 was an odious system of racial oppression that could not possibly be squared with the constitutional requirement of equal protection. But it is difficult to fault the Court for not writing such an opinion. For similar reasons, it is difficult to fault the Court for not spelling out all of the reasons it became convinced that state criminal justice systems needed to be reformed.

I refer to the formalist approach, rather than to Justice Black, because it is not clear that Justice Black intended to use his rhetoric in a manipulative way. That may have been a side effect of a formalist orientation that Justice Black adopted for other reasons.

- See Lee C. Bollinger, The Tolerant Society: Freedom of Speech and Extremist Speech in America 76-103 (Oxford, 1986), for a similar account and criticism of the use of formalist rhetoric in interpreting the First Amendment. Bollinger suggests that defenders of free speech, including judges, speak as if the dictates and foundations of the First Amendment were much clearer than they actually are; and that they do so because they fear that any admission of uncertainty will encourage the ever-present forces of mass intolerance. Bollinger comments on the "elitism" of this approach to the First Amendment. Id at 101.

10347 US 483 (1954).

1 Charles L. Black, Jr., The Lawfulness of the Segregation Decisions, 69 Yale L J 421, 428 (1960). 
There is, however, a difference between not fully spelling out all of one's reasons for reaching a conclusion and stating supposed reasons that are not true-such as (in most cases), "the Framers decided this question for us," or "the text requires this result." The defense of the use of the Bill of Rights as a code is that it accomplished important objectives that otherwise might not have been achieved. The problem with this conception of the Bill of Rights is that it raises the question of the extent to which manipulatively false rhetoric is permissible in public life. That is a difficult question; it is possible that this approach oversteps the line.

\section{The Bill of Rights As a Structural Corrective}

A second conception of the Bill of Rights treats it as a way of correcting certain structural deficiencies in representative government. This conception differs sharply from the view that treats the Bill of Rights as a code. It does not necessarily rely on specific language; it has different presuppositions and modes of argument; and, unlike the code approach, it does imply a form of judicial supremacy.

A.

The central idea of this conception is that representative government does some things badly, or at least cannot be trusted to do them well. The purpose of the Bill of Rights is to make up for these deficiencies of representative government.

The most conspicuous example of this conception is a wellknown understanding of the Free Speech Clause of the First Amendment: that the purpose of this guarantee is to ensure the proper functioning of representative government. ${ }^{12}$ Left to their own devices, officials will tend to suppress speech that is critical of them, thus preventing democratic accountability. The principal purpose of the guarantee of free speech is to keep the channels of commuhication open so that representative government can continue to operate. This understanding of freedom of speech is probably the most widely accepted view of the First Amendment today. It is, for example, the view that underlies New York Times $v$ Sulli-

12 The best-known example of this approach is Alexander Meiklejohn, Free Speech and Its Relation to Self-Government (Harper, 1948). See also Cass R. Sunstein, Free Speech Now, 59 U Chi L Rev 255, 300-14 (1992). 
van,$^{13}$ arguably the most important free speech decision of the last thirty years.

In an important sense, however, this understanding does not see the First Amendment as establishing a right to free speech at all. This reflects the defining characteristic of the structural conception of the Bill of Rights. The structural approach does not regard the First Amendment as establishing rights in the sense that this approach is concerned with the condition of the system of expression as a whole, not the fate of any identifiable individual. So long as the system is working properly-so long as channels for criticizing government officials remain open-the fate of any particular individual is immaterial. Under the structural conception, individuals' legal rights are entirely instrumental: the only justification for allowing an individual to assert First Amendment "rights" is that there is no other satisfactory way of maintaining the system-wide quantity and quality of expression that we want.

In other words, in principle the structural view of the First Amendment would allow any individual's speech to be suppressed so long as the system of free expression as a whole was functioning properly. If, for example, the President's decision to veto a civil rights bill had been thoroughly criticized in literally thousands of well-publicized statements, there would be no harm in suppressing the speech of a single individual with a small audience, all of whom had heard the same arguments many times before. That particular speech would be surplusage because it would not provide any benefit to the system of democratic accountability. The leading proponent of this view made the point explicitly: "What is essential is not that everyone shall speak, but that everything worth saying shall be said."14

In practice, of course, there are dispositive institutional reasons not to allow a free speech claim to be defeated on this basis. Courts cannot be trusted to decide when the system as a whole is functioning well or when the speech in question is truly redundant. My point is not that, under the structural approach, we ought to allow the suppression of speech in these circumstances. It is only a point about the nature of the justification that this approach offers for protecting speech.

This view of freedom of speech contrasts with what I believe is the universal understanding of freedom of religion. Religious free-

\footnotetext{
${ }^{13} 376$ US 254 (1964).

${ }_{14}$ Meiklejohn, Free Speech and Its Relation to Self-Government at 25 (cited in note 12).
} 
dom is not instrumental in the way that, under the structural approach, free speech is. Punishing a person because of her religious beliefs is unacceptable in principle, not because of institutional concerns, but because it infringes on an individual right no matter what the condition of the "system" (whatever the relevant system is). There are many non-structural justifications for free speech, of course. But the structural argument-that free speech is necessary to keep democracy functioning as it should-places freedom of speech on a different foundation from freedom of religion.

The structural conception of the Bill of Rights is the same approach generalized beyond freedom of speech. According to this conception, the Bill of Rights does not provide a code that will spur reform, nor does it protect (other than instrumentally) individual rights. Instead, it protects against certain systematic weaknesses of representative government. This idea is associated with the Carolene Products footnote, which envisions more active judicial review both of "legislation which restricts those political processes which can ordinarily be expected to bring about repeal of undesirable legislation" and of "statutes directed at particular ... minorities [because] prejudice against discrete and insular minorities may ... tend[] seriously to curtail the operation of those political processes ordinarily to be relied upon to protect them."15

In addition to the Free Speech Clause (and of course the Equal Protection Clause), many Bill of Rights' protections for criminal defendants can be understood in this way. The Cruel and Unusual Punishment Clause ${ }^{16}$ protects convicted offenders, a small and politically powerless group, against a vengeful society. The jury trial right ${ }^{17}$ ensures, among other things, a form of popular sovereignty over decisions that, because of their particularity, the legislature cannot control. The Fourth Amendment's Warrant Clause and ban on unreasonable searches and seizures help control decisions by low-level officials that are not visible enough for elected bodies to control. ${ }^{18}$

Today perhaps the most significant structural interpretation of the Bill of Rights involves the Just Compensation Clause. Structural arguments, generally associated with public choice theory, are

${ }^{16}$ United States v Carolene Products Co., 304 US 144, 153 n 4 (1938). For a leading statement of this generalized approach, see John Hart Ely, Democracy and Distrust: $A$ Theory of Judicial Review (Harvard, 1980).

16 US Const, Amend VIII.

17 US Const, Amend VI.

${ }^{18}$ See Ely, Democracy and Distrust 96-99, 172-73 (cited in note 15). 
increasingly offered as reasons for courts to expand the Just Compensation Clause, and there are signs that those arguments are becoming increasingly influential.

The public choice structural argument is, roughly, that when a representative body regulates or redistributes property, it systematically tends to benefit well-organized interest groups at the expense of more diffuse groups, to the detriment of society as a whole. If the Just Compensation Clause were applied to a wider range of government actions than it now covers, the government would be precluded from adopting some or all redistributive measures and would be forced to internalize the costs of regulatory actions. This, it is said, would reduce the distorting effects of interest group power. ${ }^{19}$ This argument-my concern is not whether it is correct-parallels the New York Times $v$ Sullivan approach to freedom of speech; both reflect a structural conception of a provision of the Bill of Rights.

The structural view is not the only possible understanding of the Just Compensation Clause. One might see it as protecting individual rights non-instrumentally. That is, quite apart from any arguments about the propensities of representative government, it is an unacceptable invasion of my liberty for the government to seize my car or my house without compensation. This understanding of the Just Compensation Clause belongs to the third conception. It does not justify as sweeping an interpretation of the Clause as the structural view; it does not preclude regulatory and redistributive actions wholesale. Rather, it just forbids actions of a particularly intrusive kind, those likely to inflict serious psychic or material injury. Arguably the Just Compensation Clause is already interpreted to prohibit this kind of government action.

The structural argument, by contrast, would expand the Just Compensation Clause to reach government actions that cannot plausibly be described as affronting human rights in the same way as a seizure of one's personal possessions. (Not every structural understanding of the Just Compensation Clause would call for such an expansion, but the influential public choice structural argument now being made in many circles does.) For example, much of what

19 Richard A. Epstein, Property, Speech, and the Politics of Distrust, 59 U Chi L Rev 41 (1992), is an example of the argument for interpreting the Just Compensation Clause in this way. The public choice argument about the defects of representative government is summarized in Einer Elhauge, Does Interest Group Theory Justify More Intrusive Judicial Review?, 101 Yale L J 31, 35-43 (1991), which, however, questions whether that argument, even if correct, justifies an expanded judicial role. 
is offensive about the classic seizure of an individual's property is the surprise and sense of insecurity it engenders. But regulation routinely occurs in volatile business settings in which it does not have these effects. If a person is fully prepared to see the market cause the value of her investment to fluctuate by thirty percent, government regulation reducing its value by, say, one percent, is unwelcome but cannot be compared, in the effect it has on the individual, to the uncompensated seizure of an individual's possessions. The argument against such regulation is structural: given the propensities of representative government (the argument goes) there is an unacceptable risk that the regulation will diminish overall well-being. It is not an argument based on the effects the regulation has on identifiable individuals.

B.

The structural conception of the Bill of Rights has its own presuppositions. They operate whether the structural conception is applied to a particular provision, or to no provision in particular-a legitimate thing to do, under this conception, as I will argue below.

The most significant presupposition is judicial supremacy. Unlike the other conceptions, the structural conception of the Bill of Rights necessarily presumes that courts will be the primary enforcers. The whole point of a bill of rights, according to this conception, is to withdraw issues from the legislature. Recall that this was not true of the formalistic conception of the Bill of Rights as a code, and as I will argue shortly, it is not true of the third conception, which treats the Bill of Rights as a charter of fundamental individual liberties. Under each of those conceptions, it would make sense to have a bill of rights without the institution of judicial review. A bill of rights might be addressed solely to a sovereign legislature: the English Magna Carta, Petition of Right, and Bill of Rights were all addressed to the sovereign King or Queen in Parliament; some colonies and states had constitutions without judicial review; and international declarations of human rights are addressed to sovereign governments and not generally enforced by courts. But under the structural conception, the purpose of a bill of rights is to authorize courts to correct the legislature's failings. It would, according to this conception, be otiose to have a bill of rights without judicial review. The connection between judicial review and a bill of rights, so natural to Americans, is a necessary connection only for the structural conception. 
The other crucial presupposition is a relatively complete theory of how a well-functioning legislative process would work. You cannot draw any conclusions about how much speech is needed to protect representative government unless you know what representative government consists of and how it should function. Even more obviously, you cannot say which groups need judicial protection because they lack sufficient power, and which "interest groups" have too much power, unless you have a theory about how the legislative process should operate.

This point is significant because the underlying theory is often left implicit. The Carolene Products formulation "discrete and insular minorities," for example, begs many questions about which groups need special protection in a democratic system. Many theories about "rent seeking" in the political process seem simply to assume, without justification, that the only legitimate function of the political process is to correct market failures. A particular structural conception cannot be justified unless the underlying theory of the democratic process is also justified.

\section{C.}

The principal mode of argument under the structural conception is one of comparative institutional competence. A court should invalidate a statute if that statute is within a class of measures that are likely to be the product of some legislative dysfunction, and if the courts are likely to correct the legislative error. In every case, under this conception, that is the primary issue.

Under the structural conception the words of the document are incidental, and formalist arguments should play no role. This is perhaps not obvious, because many advocates of the structural conception also invoke the words of the document. The Carolene Products footnote, for example, suggested that active judicial review would be appropriate, not only where the political process might not function well, but also "when legislation appears on its face to be within a specific prohibition of the Constitution, such as those of the first ten amendments." 20

The structural conception, however-taken by itself, not in combination with another conception-does not justify this kind of resort to the specific language of the document. It calls for active judicial review of those issues, but only those issues, that the legislative process will systematically handle badly, and the judicial

20 Carolene Products, 304 US at 153 n 4. 
process will systematically handle better. As I suggested earlier, a plausible claim can be made that many of the provisions of the Bill of Rights concern such issues. The Framers of the Constitution and the Bill of Rights may even have had such systemic dysfunctions in mind. But the justification for judicial intervention remains the structural argument, not the text. If the text is to be cited as authoritative in itself, some other justification will be needed. ${ }^{21}$

Of course, as I said at the outset, it might be possible to hold a view that combined structural and formalist elements. One might say, for example, that the text is authoritative but that where it is ambiguous it should be interpreted according to structural arguments. ${ }^{22}$ One would then have to justify the use of those two conceptions in combination. The view that the text is binding might be justified by arguments about authority or precedent. But structural arguments alone-that is, arguments about institutional competence-do not by themselves justify the reliance on text.

\section{The Bill of Rights As a Charter of Fundamental HUMAN RightS}

A.

The third conception of the Bill of Rights is probably closest to the popular image. It treats the Bill of Rights as a charter of fundamental human rights-those rights that an individual should have against the state in any society.

In one sense this conception is the easiest to justify. Everyone agrees in the abstract that there are human rights that no society should abridge. And there is nearly universal agreement on many of those rights: religious toleration, a general right to dissent, freedom from arbitrary punishment, and freedom from slavery and oppressive racial or ethnic discrimination. Every society should have, somewhere, a conception of these rights-either written down in a bill of rights, or informally understood in the culture. It is natural to view the Bill of Rights as our society's recognition of these basic human rights.

${ }^{21}$ See Charles L. Black, Jr., Structure and Relationship in Constitutional Law 11-12 (Ox Bow Press, 1985). degree.

${ }_{22}$ Ely, Democracy and Distrust (cited in note 15), takes this approach at least to a 
This conception of the Bill of Rights has some overt advocates. ${ }^{23}$ But the list of its advocates does not begin to convey how central this conception is in history and in current practice. A claim that a government practice is morally wrong is always a powerful argument in a controversy over any provision of the Bill of Rights. If you persuade a judge that a certain practice would be condemned if, for example, another country engaged in it, you are well on your way to convincing the judge to interpret some provision of the Constitution to forbid that practice.

In controversies about the Bill of Rights-for example, a case, not controlled by precedent, involving the First Amendment, the Fourth Amendment, or the Due Process Clause-the principal dispute often concerns not the text or the history of the particular provision (both of which are often indeterminate or otherwise unhelpful) but whether the challenged government action is, all things considered, a morally unacceptable way to treat individuals. The litigants will use moral terms like "fair," "reasonable," or "justified on balance," and the judges will think in (or react in) those same terms. Does this form of government involvement with religion endanger religious liberty in a way that seems unfair to some group? Does permitting this restriction on speech open the door to government abuse of political opponents? Does this police investigative practice interfere with citizens' legitimate interests in privacy and security? Is this a fair way to adjudicate this class of disputes, given the various interests at stake? Is this form of punishment barbarous? All of these questions reflect a conception of the Bill of Rights under which its purpose is to protect fundamental human rights.

Like the structural conception, this view of the Bill of Rights fits uneasily with its language. Many of the rights explicitly guaranteed by the Bill of Rights are fundamental in the sense that no civilized society would deny them. But some rights that virtually everyone would agree are fundamental in this sense are not explicitly enumerated in the Bill of Rights. Freedom from chattel slavery and from oppressive racial discrimination had to await the Thirteenth and Fourteenth Amendments. The right to bodily integrity, even in the barest sense of a right not to be beaten up by the police, is not obviously guaranteed by language anywhere in the Bill

${ }^{23}$ See, for example, Ronald Dworkin, Unenumerated Rights: Whether and How Roe Should Be Overruled, 59 U Chi L Rev 381 (1992); Michael Perry, The Constitution, the Courts, and Human Rights (Oxford, 1982). 
of Rights. ${ }^{24}$ In my view, a greater right to bodily integrity, of the kind anti-abortion laws violate, is also fundamental and is not obviously described in the text of the Bill of Rights either. (The abortion question is truly difficult, but only because the interest in fetal life is at stake.) A right to privacy in the sense of keeping certain private information from the government is in the same category. ${ }^{25}$ We would not regard a society as just (or maybe as even a society) if it provided no protection against private violence; but that right, according to the Supreme Court, is not in the Constitution at all. ${ }^{26}$ There are many other possibilities. And, of course, there is the problem that the text of the Bill of Rights itself applies only to the federal government, not the states.

Finally, not all of the rights enumerated in the Bill of Rights are fundamental in the sense that no civilized society would deny them. The states may dispense with grand jury indictments and civil juries, and that is not a violation of fundamental human rights. There are just societies in the world that do not observe the privilege against self-incrimination or some of the aspects of an adversary criminal justice system prescribed in the Sixth Amendment. There are also just and tolerant societies with established churches.

It might be argued that conditions peculiar to our society make, say, established churches and nonadversary criminal proce-

24 Three provisions of the Bill of Rights arguably protect this right: the Fourth Amendment's prohibition against unreasonable searches and seizures "of persons, houses, papers, and effects"; the Due Process Clause of the Fifth Amendment; and the Cruel and Unusual Punishment Clause of the Eighth Amendment.

The Fourth Amendment, however, seems to refer simply to detention, not to battery. That is the ordinary meaning of "seizure," and the parallelism suggests that the Amendment applies only to actions of a kind that could also be taken against houses, papers, and effects-none of which can be subject to a battery. The most obvious meaning of "liberty" in the Due Process Clause is again freedom from physical restraint, especially since that Clause contemplates that "liberty" can be taken away if due process is provided, and no process justifies police brutality. The narrow definition currently given to "punishment" in the Cruel and Unusual Punishment Clause, see, for example, Bell $v$ Wolfish, 441 US 520, 537-39 (1979), would exclude many acts of police brutality.

Of course, any of these provisions can be interpreted to prohibit police brutality without stretching their language beyond recognition. But if that is the test-whether the language would be stretched beyond recognition-then there are few rights that anyone would advocate that cannot be fit within some provision of the Bill of Rights.

${ }^{25}$ Everyone would agree, I believe, that no reasonably just society would permit the government unlimited power to monitor its citizens' private conversations. In Katz $v$ United States, 389 US 347 (1967), the Court found this right in the Fourth Amendment. But as Justice Black's dissent showed, this outcome is not by any means obvious from the language of that Amendment. See id at 364-74 (Black dissenting). See also Whalen v Roe, 429 US 589 (1977); and Roberts v United States Jaycees, 468 US 609 (1984).

${ }^{26}$ DeShaney $v$ Winnebago County Department of Social Services, 489 US 189 (1989). 
dures unacceptable here, even if they might be benign elsewhere. But even if this argument is accepted, the fundamental rights conception of the Bill of Rights has powerful implications: it suggests that certain provisions are to be interpreted less generously than others.

It seems entirely plausible, for example, that religious establishments in this country (unlike, I suppose, the current Church of England) would seriously violate religious freedom. Even so, under this conception of the Bill of Rights, the Establishment Clause need not be interpreted with the same sympathy and scope as the Free Exercise Clause. The Free Exercise Clause secures a fundamental human right and should be interpreted generously. In contrast, the Establishment Clause (according to this view) should be interpreted narrowly, to forbid only those forms of government recognition of religion that really do endanger religious liberty. There might be structural justifications for giving a more sweeping reading to the Establishment Clause. For example, the Court at one time suggested that the special danger posed by religiously divisive political controversies was a reason for restricting the power of the government to aid religion. ${ }^{27}$ And there might be formalist justifications as well, for example if one thought (again plausibly) that there are common forms of government aid to religion that in fact violate religious liberty but are not widely perceived that way. ${ }^{28}$ But to the extent that one adopts the fundamental rights conception, one cannot simply say that the Establishment Clause (or the Self-Incrimination Clause, or the Contracts Clause) is as much a part of the Constitution as the Free Exercise Clause (or the Cruel and Unusual Punishment Clause, or the Free Speech Clause) and should be interpreted as generously.

B.

The fundamental rights conception, unlike the structural conception, does not presuppose judicial supremacy. Even a society without judicial review could profitably adopt a bill of rights: it would be used in political controversies as a means of persuading the legislature. As I said before, there are many examples of human rights charters adopted without a system of judicial review, ranging from the English Magna Carta, Petition of Right, and Bill

\footnotetext{
${ }^{27}$ This was the notion of "political entanglement." See Michael W. McConnell, Religious Freedom at a Crossroads, 59 U Chi L Rev 115 (1992), for criticism of this notion.

${ }^{28}$ See, for example, Mary E. Becker, The Politics of Women's Wrongs and the Bill of "Rights": A Bicentennial Perspective, 59 U Chi L Rev 453 (1992).
} 
of Rights, to the constitutions of some colonies and states, to international declarations of human rights today.

The fundamental rights conception does have one important, and superficially controversial, presupposition: it presupposes some form of moral objectivity. That is, it presupposes that in a wide range of cases, there are right and wrong answers to moral questions. Otherwise it would not be possible to say that certain rights are fundamental, and that all societies should protect them.

The presupposition of moral objectivity is important not so much because it is doubtful as because many lawyers reflexively resist it. In fact, the opposite position-that two contradictory moral judgments might each be right-is difficult to make sense of, much less to justify. Some form of moral objectivism is almost surely correct. But the notion that judges who rely on moral arguments are "imposing their own values" is a familiar one. This notion does reflect a legitimate concern about institutional competence. That is the real concern with the fundamental rights conception, not the very dubious view that there is in principle no right or wrong in moral matters.

If it is to be implemented, the fundamental rights conception of the Bill of Rights must defend certain presuppositions about institutional competence. For example, even if moral judgments are, in principle right or wrong, it does not follow that judges are more likely to get them right if they make up their own minds than if they defer to a popularly elected body.

In fact, the questions of institutional competence raised by this conception are very difficult. There are serious problems with leaving the difficult moral questions raised by a bill of rights to any of the institutions that might possibly decide them. Courts can be arbitrary and willful, and have various kinds of class biases; legislatures are subject to popular passion, prejudice, and misjudgment, as well as the dysfunctions identified by public choice theory; and individuals are self-interested and sometimes irrational. ${ }^{29}$ Undoubtedly different institutions are best suited to determine the scope of different rights, but in any event some difficult judgments about institutional competence must be made before the human rights conception can be implemented.

${ }^{29}$ Two examples of positions that leave difficult moral judgments about fundamental rights to individuals are the "pro-choice" position in abortion and the view that private charity should be responsible for all redistributions of wealth. 
C.

The characteristic modes of argument of the fundamental rights conception follow from these presuppositions. The principal argument will be, at bottom, about whether a particular government practice is morally right or wrong. Interestingly, the rhetoric usually avoids explicit moral language; it never uses the term "moral" and often shies away from words like "unjust." Instead the rhetoric uses the terms of the Constitution-freedom of religion, freedom of speech, and so on-or, if necessary, technicalsounding terms like "unreasonable burden" and similar "balancing" language.

It might be objected that of course the courts and advocates use the terms of the Constitution; that is what they are supposed to be interpreting. But according to the fundamental rights conception, the correct way to interpret the terms of the Constitution is to recognize that it protects fundamental human rights. This conception is supported by existing practices: as I suggested earlier, in practice, in a wide range of difficult constitutional cases, it is generally accepted that the best legal argument is often an argument about fairness or decency - that is, a moral argument. In fact, the reluctance to use overtly moral language reflects the reflexive subjectivism I criticized, as well as a legitimate concern-related to the formalist conception - that a decision justified in terms of the text will be more readily accepted than one justified in explicitly moral language.

The other mode of argument under the fundamental rights conception ought to be institutional competence. Sometimes the institutional questions are settled by precedent or some comparable source, just as questions about the content of rights can be settled by such sources. In most systems there is no point in arguing about whether the courts or the legislature should decide whether a particular measure abridges religious freedom; that question was settled long ago, by deliberate act or, more likely, by culture. But often questions about institutional competence will be central-for example, in deciding the extent to which the courts will oversee police practices; or the way courts will attempt to control government actions that are impermissibly motivated; or the appropriateness of so-called "affirmative" rights to government aid (such as subsistence, or the right to be free from private violence). Even under the fundamental rights conception, it is a non sequitur to say that because it is morally wrong for the government to act in a certain way, the courts should prohibit it from doing so. 


\section{Conclusion: Five Faldacies in Interpreting the Bill of} RIGHTS

I have suggested that there is no single, obviously correct conception of the role of a bill of rights. Instead, our history and current controversies reflect three competing conceptions, each with different presuppositions and modes of argument, and of course with different implications for how the Bill of Rights should be interpreted.

As I said at the outset, one need not choose one of these conceptions; they can be coherently combined in various ways. What is important is not to invoke arguments without justifying the conception from which those arguments are derived. As a conclusion, I will suggest five common fallacies that, I believe, result from this error: using arguments from a conception that has not yet been justified.

A. Where Is It in the Text?

Many of those who make this argument think that the lack of explicit textual support is an unanswerable criticism. Some of those against whom it is made think it is not a criticism at all, because the text is (for various reasons) indeterminate. Others resort to the view that the text is only one among many factors to consider, a view that gives the impression of being irresolute and unsatisfactory. ${ }^{30}$

In fact, this argument can be a legitimate one only if some antecedent conception is justified. For example, this argument would be sound if the formalist conception-that the Bill of Rights is a code-were shown to be the only correct conception. If you can demonstrate that the Bill of Rights (or any comparable charter) should, at this time and place, be used only as a code, then you are entitled to demand a textual source for any right. One might arrive at the same place through a structural argument, for example by showing that allowing judges to go beyond the explicit text creates too much of a danger that they will abuse their power. But that will be a difficult argument to make; it will require empirical and

${ }^{30}$ It might also be said that in any debate about the interpretation of the Bill of Rights, what is "in the text" is precisely the point in dispute. In a sense, that is correct: any argument about the Bill of Rights is a claim about how the text of the Bill of Rights should be interpreted. The argument I refer to here is the claim that rights not explicitly guaranteed in the text should not be recognized. If the notion that some guarantees are "explicit" is meaningless (I do not believe that it is), see Dworkin, $59 \mathrm{U}$ Chi L Rev at 381 (cited in note 23) then this argument is all the more fallacious. 
normative premises and a way of addressing the obvious indeterminacy of the Bill of Rights.

The most prominent example of this argument today, of course, is the one made against Roe $v$ Wade. ${ }^{31}$ From one angle this argument is very puzzling, because it is not that difficult to come up with a plausible textual source for the right involved in Roe. More important, the issue of the moral status of fetal life is much more serious, presents a much more difficult question for the proponents of Roe to answer, and better reflects what the opponents of Roe are (I suspect) really concerned about. The reason much of the debate over abortion has been about the existence vel non of the right, I believe, is because the formalist view took such a strong hold during the Warren Court period. A structural or fundamental rights view would present the abortion issue in a much more useful way.

\section{B. All Constitutional Provisions Are Equal}

Justice Frankfurter and others made this argument in response to Justice Black's view, essentially adopted by the Court, that First Amendment rights occupy a "preferred position" that justifies more active judicial review (compared to property rights, for example). The argument is made today by what may be an emerging movement in favor of reviving constitutional protections for property. (It is not obvious how to measure which rights receive "more" protection; but for present purposes I assume that it can be done.) Why is it, proponents of this view ask, that the Just Compensation Clause (or the Contracts Clause) is interpreted so grudgingly, while the Free Speech Clause is interpreted so generously?

Ironically, in view of its use against Justice Black, the argument that all constitutional provisions are equal derives from the formalist view of the Bill of Rights as a code. For example, if you are trying to reform entrenched aspects of state criminal justice systems, you do not want to say that the Confrontation Clause can be interpreted flexibly to accommodate the interest in protecting victims of child abuse from cross-examination, but the Self-Incrimination Clause cannot be interpreted flexibly to accommodate the interest in obtaining confessions.

But unless you have sufficient reasons for using the Bill of Rights as a code, or can justify some other conception of the Bill of 
Rights that dictates that all provisions are "equal" in some sense, this argument is a non sequitur. Under the structural view, there is no reason to treat all provisions alike. Some provisions identify areas where the courts are superior to legislatures; others do not. Similarly, under the fundamental rights conception not all provisions should be interpreted with the same degree of generosity. As I have argued, some provisions of the Bill of Rights protect rights that are fundamental in any society; others do not. The notion that all constitutional provisions are equal sounds very appealing but is actually quite difficult to justify.

C. The Judicial Nirvana Fallacy

This is the view that either ignores institutional competence arguments or uses them selectively, in a way that overstates the capacity of courts. It takes two forms. The first adopts the fundamental rights conception without recognizing its institutional presuppositions. You cannot justify active judicial enforcement of the Bill of Rights just by showing that there are moral rights and wrongs and that provisions of the Bill of Rights can plausibly be interpreted to constitutionalize various moral judgments. One must also explain why it is better on balance for the courts to make the necessary judgments.

The other form of the fallacy identifies defects in the legislative process as a basis for more active judicial review. The problem here is a one-sided application of the structural conception, which requires a comparative judgment of institutional competence. Even if legislatures do certain things badly, there is no guarantee that courts will do them better. Any argument for more active judicial review-for example, the public choice-based argument for more vigorous judicial enforcement of property rights-must address the competence of courts as well as legislatures. ${ }^{32}$

\section{The Fallacy of Misappropriated Moral Force}

This fallacy takes advantage of the fact that many provisions of the Bill of Rights secure fundamental human rights to support an argument that is actually based on a different conception. It is the opposite of guilt by association: a provision of the Bill of Rights is treated as protecting a valuable right because other provisions, or other applications of that provision, protect valuable rights. There are several possible examples.

${ }^{32}$ See Elhauge, 101 Yale L J 31 (cited in note 19). 
Consider, first, one common treatment of the Self-Incrimination Clause, which celebrates it as a foundation of liberty. It may be desirable, all things considered, to forbid compelled self-incrimination. But there are just societies, and decent systems of criminal justice, in which defendants are required to give testimony (under, of course, carefully controlled conditions).

Many of those who celebrate the Self-Incrimination Clause do so not because it is a fundamental human right but because they want to enforce it for other reasons. For example, the Warren Court's decision in Miranda $v$ Arizona ${ }^{33}$ can be seen as using the Self-Incrimination Clause in a formalistic, code-like way, to try to control abusive practices in police interrogation. Historically custodial interrogation had been analyzed under the Due Process Clause. That approach focused attention on the abusiveness of the interrogation and, to some degree, on the likelihood that the interrogation could have produced a false confession. Miranda shifted the focus to whether the suspect had been "compelled ... to be a witness against himself," an approach that produces a different emphasis. The text did not compel this treatment of custodial interrogation, but the Miranda Court evidently believed that it was needed to combat unacceptable police practices. ${ }^{34}$ It helps, in using the Clause in this way, to take advantage of the fact that other provisions of the Bill of Rights-and for that matter, certain applications of the Self-Incrimination Clause-do protect against violations of human rights. But doing so gives the Clause an aura of moral significance that it does not fully deserve.

Another example of an argument that misappropriates moral force involves the Just Compensation Clause. Some protection for private property is surely a fundamental human right: a government with unlimited power to take property from its citizens would be tyrannical. As I outlined earlier, however, some arguments for protecting property rights, based on public choice theories, would go far beyond the level needed to secure fundamental human rights. Those structural arguments invoke the Just Compensation Clause and the idea of property rights as a bulwark against tyranny, thus trying to take advantage of the moral force of those notions. In fact, however, the expanded public choice conception of property rights must be justified in structural terms. It is an illegitimate appropriation of moral force for the public choice

${ }^{33} 384$ US 436 (1966).

34 For a discussion of these points, see Stephen J. Schulhofer, Reconsidering Miranda, 54 U Chi L Rev 435 (1987). 
conception of property rights to take advantage of the morally powerful connotations of the idea that every decent state guarantees some right of property.

\section{E. Unreflective Moral Subjectivism}

I addressed this fallacy in discussing the fundamental rights conception of the Bill of Rights. This fallacy consists of denying the authority of courts ever to consider moral issues, instead of discussing whether courts are institutionally competent to do so. The fallacy is reflected in the common claim that when courts invoke the fundamental rights conception-when they go "beyond the plain language," or, in some versions, when they go beyond structural justifications for judicial review-they are necessarily just "imposing their own values."

The fallacy lies in assuming that it is impossible to reason about moral judgments and to arrive at answers that are right or wrong. As I said earlier, moral subjectivism is in fact difficult to defend. Indeed, few of those who make the "judges' own values" argument are really moral subjectivists. They would not say, for example, that it is meaningless to make moral arguments to legislators or administrators, or that when parents or teachers or public figures purport to make moral arguments to children they are just "imposing their own values" instead of making claims that we can decide are right or wrong by reasoning about them.

The "judges' own values" argument does reflect a real concern, but one that raises complex and difficult issues. Plausibly stated, the argument can take one or more of four forms: (1) judges are more likely to decide a certain category of moral issues wrongly than legislatures are; (2) whether or not judges are more likely to make the wrong decision, the decisions will be wrong in a worse way (for example, the judges' errors will reflect some form of class bias, while legislatures' errors will be more randomly distributed); (3) although judges' decisions may be right, they will have adverse effects because society has not exercised its own capacities to decide $^{35}$ or (4) even if judges' decisions are more likely to be right, democractic decisionmaking has instrinsic moral value that outweighs the risk of error. Each of these claims is plausible; each is surely right sometimes; but each must be justified. The simple,

\footnotetext{
${ }^{36}$ For example, the decision may be less likely to take hold than one arrived at through democratic means, or the society's capacities to decide certain kinds of issues may atrophy because it relies too much on judges to decide them.
} 
rhetorically effective invocation of the danger of the "judge's own values" is not an adequate way to deal with these issues.

The Bill of Rights is a powerful symbol in our society, and the idea of a bill of rights is an increasingly powerful symbol in the world. But symbols, of course, do not interpret themselves, and the Bill of Rights will not be anything in particular until we decide what to make of it. In our history, and in current controversies, the Bill of Rights has been at least three different things. We should not underestimate the difficulty of deciding what we want it to be in the future. 
, 